\title{
ACTIVE TECTONIC AND VOLCANIC MOUNTAIN BUILDING AS AGENTS OF RAPID ENVIRONMENTAL CHANGES AND INCREASED ORCHID DIVERSITY AND LONG-DISTANCE ORCHID DISPERSAL IN THE TROPICAL AMERICAS: OPPORTUNITIES AND CHALLENGES
}

\author{
STEPHEN H. KIRBY \\ Scientist Emeritus, U.S. Geological Survey, Menlo Park, CA 94025, U.S.A. \\ Visiting Professor, Faculty of Sciences, Tohoku University, Sendai, Japan \\ Honorary Professor, Institute of Risk and Disaster Reduction, University College London, \\ London WC1E 6BT, U.K. \\ Research Associate, Lankester Botanical Garden, University of Costa Rica \\ stevenlyle@icloud.com
}

\begin{abstract}
Tropical Latin America is a nexus of tectonic plates whose relative motions have led to rapid tectonic and volcanic mountain building in late Neogene time. Tropical mountain building, in turn, leads to highland "cloud forest" microclimates with increased rainfall, lower diurnal temperatures, and diverse microclimates. I have previously emphasized how the geologically recent growth of mountains has been localized in Central America and that this is likely a factor in the high diversity and endemism in those highlands. This paper will show that Andean uplift accelerated at $\sim 15 \mathrm{Ma}$ ago and $\sim 5 \mathrm{Ma}$ BP and continues to this day. This process evolved geographically among the cordilleras of the region. Givnish and others recently presented phylogenomic evidence that the diversity of many epiphytic orchids, including tribes found in the neotropics, also accelerated during this time interval. Phylogenetic investigations of tropical orchid pollinators have shown that acceleration in speciation in such pollinators as hummingbirds, orchid bees, and flies occurred over this same time frame, suggesting that geologically driven environmental changes may have acted in concert with changes in orchid biology to speed up orchid diversity in these highlands. I also review some of the long-distance dispersal processes of orchids in the tropical Americas. River systems draining the Colombian Andes discharge into the Caribbean Sea and current-driven log-raft drifts and air suspension during cyclonic storms transport plants and animals from east to the west. Lastly I emphasize the need for the more information on orchid floras and species distribution in this hotspot.
\end{abstract}

KEY WORDS: Andean orchids, mountain building and orchids, Neotropics, orchid diversity, orchid species distribution

Prologue. It is the author's pleasure to acknowledge the important contributions of Calaway Dodson to neotropical orchid biogeography and diversity and his encouragement of the author to do research on geological processes can be important contributors to orchid diversity. In 2003 he wrote: "Given the nature of the orchids subject to [biological factors] and the changing geology and microclimates of Ecuador [my italics], rapid change in the genetic nature of populations leading to explosive speciation is possible" (Dodson 2003).

Introduction. There are few places on this planet that are as geologically active as the nexus in the tropical Americas where there are five major tectonic plates, five microplates, seven triple junctions where three plates meet, and seven trenches where one plate dives under another, a process called subduction (Fig. 1). The relative motions of these plates and microplates lead to a rapidly changing environment of tectonic mountain building by compression and thrust faulting localized along major faults and volcanic mountain building where the positions of active arc volcanic centers and volcanic chains often change largely due to changes in the nature of the incoming plate and the geometry of subducting plate. These 


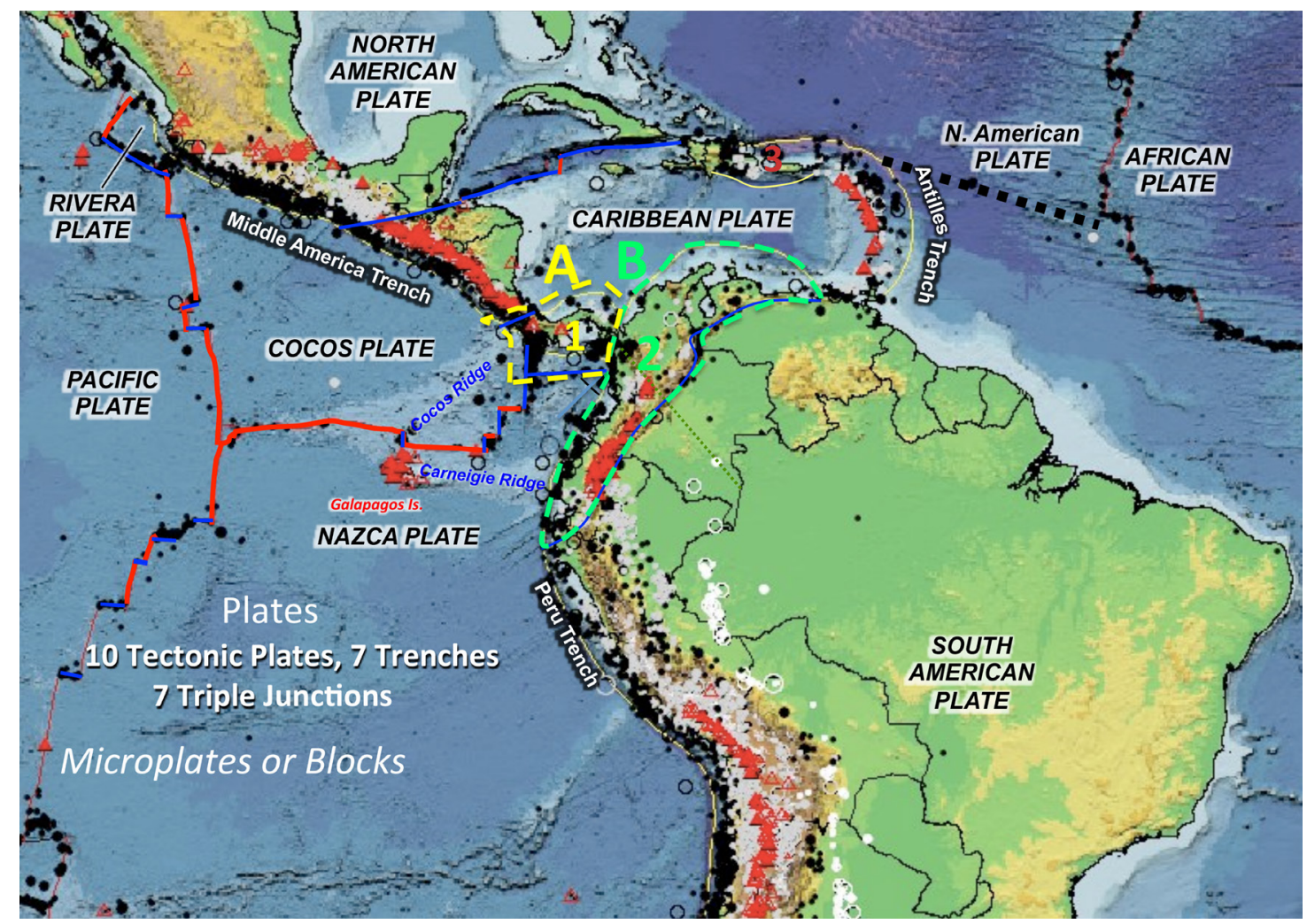

FIGURE 1. Map of neotropical orchid and tectonic diversity hotspots illustrating geologic-based environmental changes as possible drivers for orchid diversity. A) Costa Rica and Panama (Kirby, 2009) in the SE Cocos Plate and Panama/Coiba Block (marked by the yellow dashed line); B) Northern Andes Uplift: Ecuador, Colombia, and NW Venezuela (marked by the dashed green line) . Map created by the This Dynamic Planet online tools (Simkin et al., 2006). After a figure in Kirby (2009, with permission). Volcanoes: red triangles; black dots: Shallow earthquakes ( $<60 \mathrm{~km}$ depth); Gray dots: Deeper earthquakes; Red lines: ocean spreading centers; blue lines: transform or strike-slip plate boundaries; yellow lines: trenches where subduction begins.

changes in the neotropics have been documented using radiogenic isotopes and paleontology, palynology, and stratigraphic and other geologic and geophysical methods used both on land and under the ocean. Present-day relative plate motions are indicated by the distribution of earthquakes and GPS measurements. The development of a tectonic model for this region that draws upon these observations and is paralleled by increasingly precise dating of branch points in the orchid tree of life and those of several groups of orchid pollinators. One aim of this paper is to compare the geologic dates of these geological and biological events and discuss the insights that can be drawn from these comparisons. Lastly, the author describes the meteorological, hydrological, and oceanographic processes that likely govern the dispersal of neotropical orchid species and the enhanced sampling and taxonomic needed in Andean Colombian and eastern Panamanian forests to test these dispersal hypotheses.

As an aid to understanding the geological time scale, I provide Figure 2, that shows the Periods and Epochs of the Cenozoic Era in the last $66 \mathrm{Ma}$ (a Ma is a mega anunm, or a million years).

Orchid species distributions in the tropics by country or major island. In Table 1 , I attempt to summarize various estimates of the number of orchid species by tropical country or island for those areas that have among the highest species counts and degrees of endemism. This is a difficult task because of differences in forest access related to security 


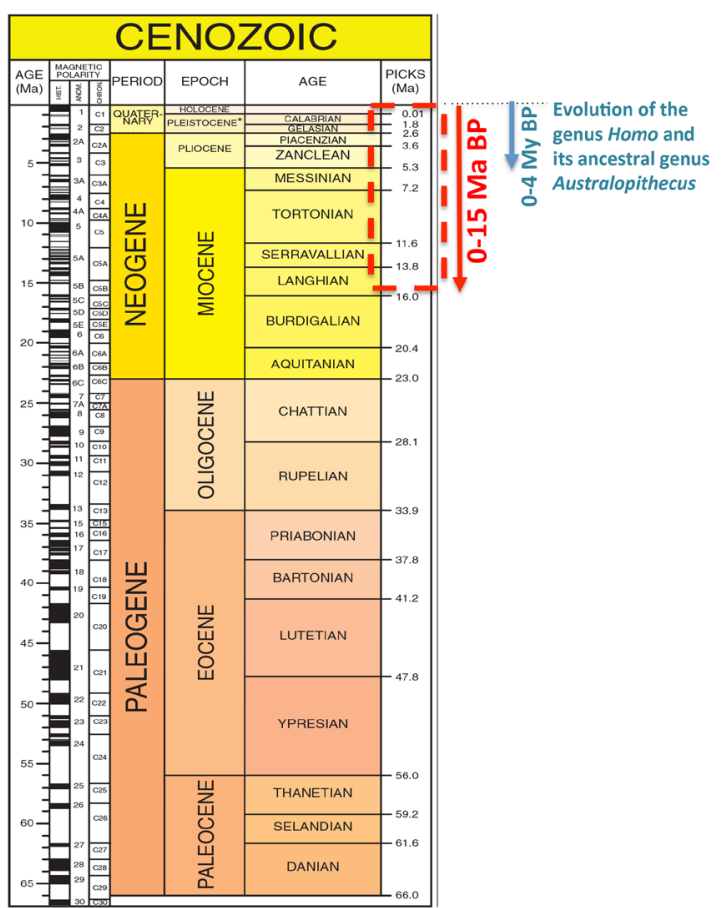

FIGURE 2. Tropical America was a very busy place in the last 15 million years, both geologically and biologically, linked by rapid environmental changes in highland micro-climates. Source: Geological Society of America Website.

issues and terrane ruggedness and isolation and in the degrees of collection and taxonomic effort. However, observers generally agree that the northern Andes (Ecuador and Colombia), SE Central America (Costa Rica and Panama) and the Island of New Guinea (West Papua, Irian Jayra, Indonesia and the main island part of Papua New Guinea) are the places where orchid species counts are large and the numbers of species new to science continue to be described. Allowing for big differences in sampling effort and taxonomic research effort, these localities have among the highest species counts and rates of endemism in the tropical world. It is notable that these areas also represent among the most tectonically complicated and active in the tropics and are also notable that they have prominent cordilleras and that these mountain ranges are young or have been rejuvenated by relatively recent tectonic uplift (middle Miocene (starting about $\sim 12-15 \mathrm{Ma} \mathrm{BP}$ and accelerating at 4-6 Ma (Pliocene) (Fig. 2). Mountain building continues in these regions, as demonstrated by the high level of seismic activity, volcanic eruptions, and geodetic measurements (using GPS instruments) of crustal deformation. Dodson (2003) and Kirby $(2007,2011)$, Ackerman $(2012,2014)$ have described how these geological processes can lead to rapid environmental changes, geographic isolation into microclimates, and mutagenesis, all-important factors in speciation. In the next section I explain the special plate tectonic settings that led to the geologically young, intense, and ongoing mountain building in these regions.

\section{Tectonics of the Costa Rica-Panama/Colombia-} Ecuador Nexus. Geological factors help give insights into the young geological history of mountain building in the tropical Americas (Fig. 1).

1) Oceanic lithosphere is being created at the Eastern Pacific Rise and Galapagos Spreading Center, resulting in two oceanic plates, the Cocos and Nazca, that are moving away from each other.

2) The North American and South American Plates are moving westward toward the Pacific Ocean, resulting in the subduction of the Cocos and Nazca Plates at the Middle American Trench (MAT) and the Peru-Ecuador-Colombian Trench (P-E-C T).

3) The Galapagos Hot Spot (GHS), a plume of magma derived from melting at deeper depths than melting at the Galapagos Spreading Center, has been erupting lavas on the Pacific Ocean floor for at least the last $20 \mathrm{Ma}$. Initially, the GHS was under the Nazca Plate and submarine lavas and small volcanoes have left a volcanic track of thickened crust as the Nazca moved over the GHP. Eventually the GSC moved over the GHS and began adding its lavas to the GSC lavas, creating thicker oceanic crust and two distinct ridges oriented parallel to the directions of plate motions relative to the GHP position: the $\sim$ NE-Trending Cocos Volcanic Ridge (CCVR) on the Cocos Plate and the east-trending Carnegie Volcanic Ridge (CVR) on the Nazca Plate (Fig. 3).

Because subduction of ridges create a partial obstruction to subduction when they reach a trench, these two volcanic ridges caused near coastal tectonic deformation landward of the middle American Trench and Peru-Ecuador-Colombia Trenches. These two zones of deformation had profound effects in mountain building in Costa Rica and Panama and in 
TABLE 1. Selected orchid species diversity in the Tropics.

\begin{tabular}{|c|c|c|c|c|c|}
\hline Country or Region & $\begin{array}{l}\text { Estimated Number } \\
\text { of Orchid Species }\end{array}$ & $\begin{array}{l}\text { Land Area, } \\
1000 \mathrm{~km}^{2}\end{array}$ & $\begin{array}{l}\text { No. Species/1000 } \\
\mathrm{km}^{2}\end{array}$ & $\begin{array}{l}\text { Maximum Age } \\
\text { of Elevation } \\
\text { Start, Ma }\end{array}$ & Notes \\
\hline $\begin{array}{l}\text { New Guinea Island } \\
\text { (Micro-Continent } \\
\text { = West Papua + } \\
\text { Papua New Guinea) }\end{array}$ & $\begin{array}{l}2759^{1} \\
3200^{2}\end{array}$ & $\begin{array}{l}786 \quad(\sim \\
235 \text { in the } \\
\text { Central } \\
\text { Cordillera) }\end{array}$ & $\begin{array}{l}3.5(11.7) \\
4.1(13.6)\end{array}$ & $\sim 12$ & $\begin{array}{l}\text { Severely } \\
\text { undersampled; 98\% } \\
\text { endemic! }^{1}\end{array}$ \\
\hline Ecuador & $4056^{3}$ & \begin{tabular}{|c}
248 \\
$\begin{array}{c}(128 \text { minus } \\
\text { the Amazonia } \\
\text { lowland) }\end{array}$ \\
\end{tabular} & $16.4(31.7)$ & $\begin{array}{l}\quad<15 \\
\text { acceleration } \\
\text { at } 4-6\end{array}$ & $\sim 20 \%$ endemic $^{3}$ \\
\hline Colombia & $\begin{array}{r}3960^{4} \\
4270^{5} \\
4354^{6}\end{array}$ & $\begin{array}{l}1197.4(794 \\
\text { minus the } \\
\text { Amazonia } \\
\text { lowland) }\end{array}$ & $\begin{array}{l}3.3(5.0) \\
3.6(5.4) \\
3.6(5.4)\end{array}$ & 4 and 15 & $\begin{array}{l}\text { Undersampled and } \\
\text { underreported. } \\
\sim 37 \% \text { endemic }{ }^{6} \text {. }\end{array}$ \\
\hline Panama & $1360^{7}$ & 74.3 & 18.3 & $\begin{array}{l}4 \text { to } 15 \\
\text { (Seaway } \\
\text { closure) }\end{array}$ & $\begin{array}{l}\text { Under-sampled especially } \\
\text { east of Canal Zone. } \\
21.7 \% \text { endemic }^{7}\end{array}$ \\
\hline Costa Rica & $\begin{array}{l}1316^{8} \\
1461^{9} \\
1519^{10} \\
1598^{11}\end{array}$ & 51.1 & $\begin{array}{l}25.7 \\
28.6 \\
29.7 \\
31.3\end{array}$ & 0.5 to 7 & $\begin{array}{l}\text { Growth in species } \\
\text { counts due to increased } \\
\text { sampling effort and } \\
\text { improved taxonomic } \\
\text { methods. } \\
\sim 30 \% \text { endemic }{ }^{12}\end{array}$ \\
\hline
\end{tabular}

References Cited in this Table

1. Schuiteman and de Vogel, (2001, 2002, 2005, 2006, 2008, 2010); 2. Papua New Guinea Orchid News [http://www.orchidspng. com/orfam.html accessed 9 March' 2016]; 3. Dodson, C. (1993-2004) ; 4. Sarmiento-Téllez (2006); 5. Betancour, Toro-González, and Valencia (2015); 6. Valencia and Betancour (2015); 7. Bogarín (2014); 8. Pupulin (2002); 9. Ossenbach, Pupulin, and Dressler (2007); 10. Bogarín (2011); 11. Bogarín et al. (2013); 12. Bogarín, D., personal communication on 10 March 2016.

the North Andes (Andean Ecuador-Colombia-Western Venezuela). Such collisions build tectonic mountains in several ways:

1) Collisions can create thrust faults and folds that shorten and thicken the crust and thereby raise elevations (Fig. 1). An example is the Fila Costeña and Talamanca Range of near-Pacific coastal Costa Rica. The birth of the Fila Costeña and the rejuvenation (young uplift) of the Talamanca Range are thought to be largely a consequence of the collision of the Cocos Ridge and rough seafloor of the GSC with the Pacific margin of Costa Rica. These events began sometime between late Neogene time and continued into the Quaternary (Fig. 2).

2) In some tectonic settings, microplates are created that move sideways of the collision direction, a process termed tectonic escape (Fig. 3 and 4). Part of the eastern motion of the Panama Block relative to South America may be attributable to eastward tectonic escape of the Panama Block (Microplate)
(La Femina et al. 2009, La Femina 2011). A welldocumented example is the tectonic escape of the North Andean Block (Microplate) (NAB) of Andean Ecuador and Colombia (Fig. 3) that is shown by the measured motions of this Block relative to the interior of the South American plate (Amazonia) based on GPS measurements (Fig. 4). Those motions may be resolved into internal strains in the NAB: an internal shear $\sim$ parallel to the Colombian Trench and a shortening perpendicular to the Trench. These deformations are accomplished by strike-slip faulting (having horizontal slip parallel to the $\sim$ NE-trending vertical fault plane) and thrust faulting roughly perpendicular to the Colombian Trench. The NAB is thrust over the Caribbean Plate along its northern boundary (the North Colombian Thrust zone. The beginning of the collision of the Carnegie Ridge and the creation of the NAB has been dated from marine geology evidence of the age of the initial opening of the Guyaquil Canyon, a rift on the trailing edge of the 


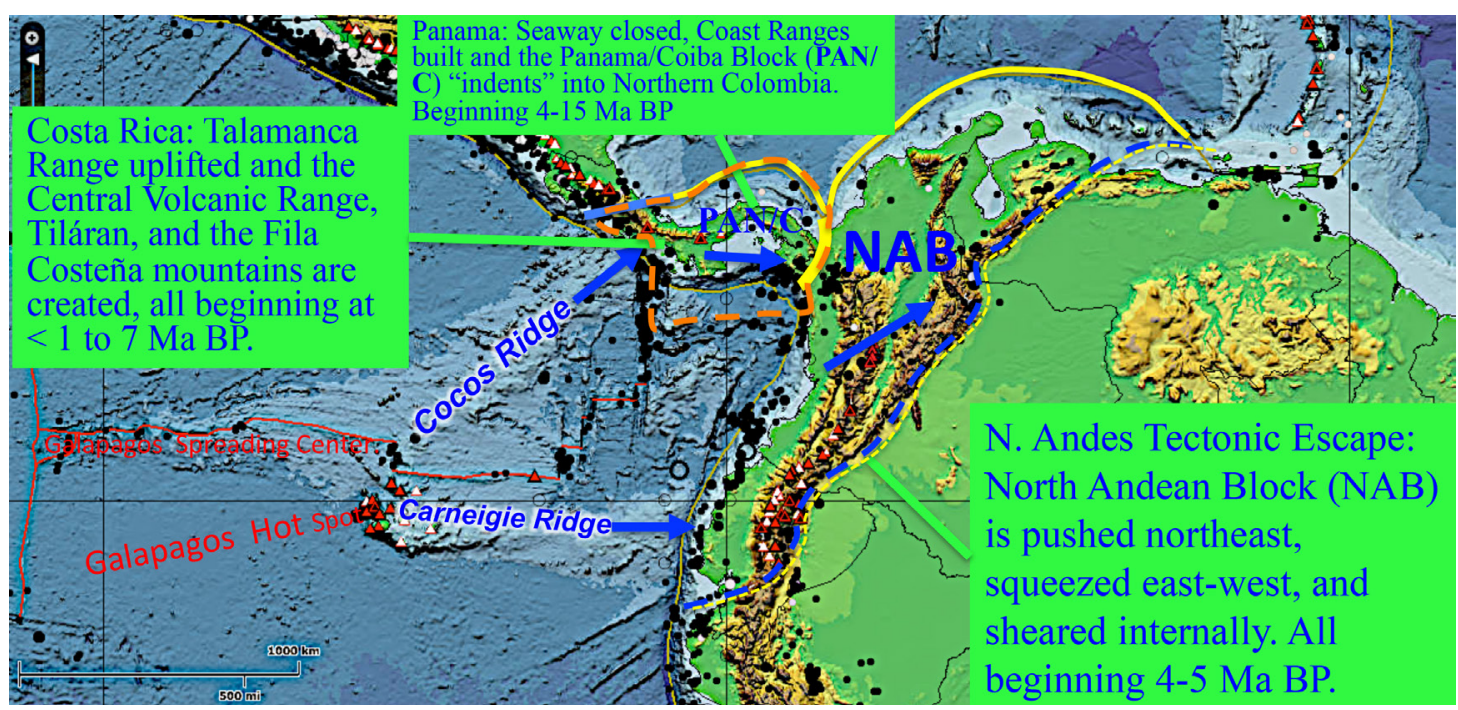

FIGURE 3. Plate-tectonic causes of young mountain building in the Tropical Americas. Blue arrows indicate motions relative to the South American Plate (SAM). The two major drivers of these geological changes are: 1) Collision of the volcanic ridges produced by the Galapagos hot spot with Costa Rica and S. America and collision of the rough seafloor produced by the Galapagos Spreading Center and 2) Collision of the Panama/Coiba Block (PAN/C) and the North Andean Block (NAB) with South America, beginning in the time interval 4-15 My BP. These mountains have high elevations: Colombia and Ecuador have 20 peaks above $5000 \mathrm{~m}$. Western Venezuela has 2 peaks near $5000 \mathrm{~m}$. Costa Rica and Panama have 6 peaks above $3400 \mathrm{~m}$. Same color symbols as in Fig. 1. Blue arrows represent motions of the PAN/C and NAB with the South American Plate.

NAB: 4 to 6 Ma BP (Collot et al. 2009, Nocquet et al. 2014). The combined squeezing and shearing motions in Andean Ecuador/Colombia/Western Venezuela (Nocquet et al. 2014) are evident in the pattern of earthquake distribution in the region (Figure 5), especially on the eastern margin of the $\mathrm{NAB}$. Although the ancestral Andes certainly were built well before 4-6 Ma BP, most of the presentday high elevations of the northern Andes can be ascribed to the tectonic effects of the collision of the Carnegie Ridge. It is also worthwhile that many other independent observations, such as the dating of Andean uplift by fission-track methods and the onset and acceleration in sedimentation in the Amazon delta derived largely from the Andes show that such dates are in the same timeframe of tectonic uplifts discussed above (Hoorn et al. 2010).

3) Mountains can also be built by volcanic action at volcanic centers (red triangles in the maps of Fig. 1 and 3). Volcanic chains in subduction zones tend to be stratovolcanoes built by composites of lava flows and volcanic ash (technically tephra) and have the conical shapes of the famous Japanese straovolcano, Mount Fuji. There are 28 stratovolcanoes in the volcanic chains of Ecuador and Colombia with elevations above $3900 \mathrm{~m}$ and nine active stratovolcanoes in Costa Rica and western Panama with peak elevations between 1900 and $3500 \mathrm{~m}$ (Siebert et al. 2011). An important point is that arc volcanoes of this type grow in elevation and are, in turn, diminished by giant explosive eruptions and erosion (Kirby 2007, 2011). Moreover, their locations relative to their nearby trenches typically change over geologic time (Scholl \& von Huene 1997). These changes therefore represent environmental changes associated with changes in elevation, rainfall, etc. in ways similar to tectonic mountains. And these changes can be extraordinarily fast. For example, the active Central Volcanic Range in Costa Rica with peak elevations as high as nearly $3500 \mathrm{~m}$ is less one Ma old. Arc volcanic ranges can appear and disappear depending on the nature of the incoming oceanic plate, including its deep shape after subduction. The Andes in South America 


\section{Resolve NAB: SAM Motion into Vector Components}
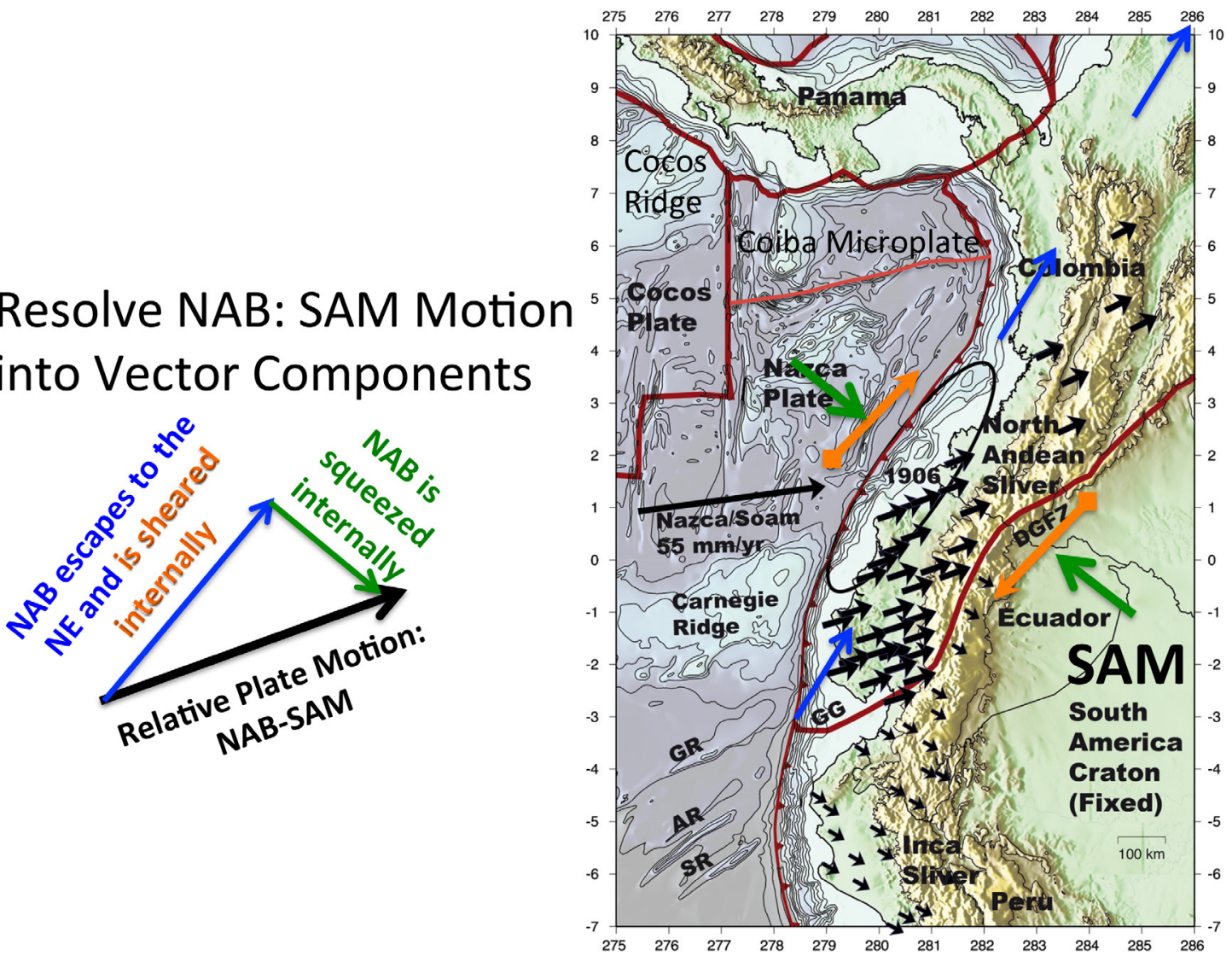

FIGURE 4. GPS measurements give insights into the most-recent speedup in the uplift of the northern Andes at 4 to 5 My

BP when the Carnegie Ridge starts to collide with South America (Collot, 2009) and the North Andean Block (a microplate) begins its tectonic escape by moving north-northeast while being sheared and squeezed. See text. After Noquet et al. (2014, with permission).

show a rich history of such changes and as such should be considered part of the environmental drivers for speciation of orchids and other biota.

After this paper was submitted and reviewed, the author attended the Regional Assembly [of] Latin American and Caribbean Seismological Commission (LACSC) in San Jose, Costa Rica (20-22 June 2016) [www.lacsc2016.com]. While the general tectonic framework described this paper was confirmed by the presentations at this meeting, new observations from seismology, geology, and GPS measurements promise to provide additional insights into the detailed time evolution of mountain building in the neotropics.

A counterpart to this tectonic nexus in the tropical Americas exists in tropical Asia along the Island of
New Guinea (West Papua, Indonesia + Papua New Guinea) and its environs (Fig. 6). There the Australia Plate is colliding with the Pacific Plate (here including the Carolyn Plate) in a broad Plate-Boundary Deformation Zone (PBDZ) prominently marked by a 2500-km long mountain chain (collectively called the Central Range) with 50 peaks having elevations above $3750 \mathrm{~m}$ (the highest in Australasia). Like the New World nexus just described, the deformation in this PBDZ represents a combination of squeezing and shearing deformation in a region of microplates the relative motions of which are producing some of the highest uplift rates in the world; just $12 \mathrm{Ma}$ $\mathrm{BP}$, the island was largely under water! (Baldwin et al. 2012). Like Colombia, the orchids of New Guinea Island are severely undersampled, but show similar promise of much larger species counts and 


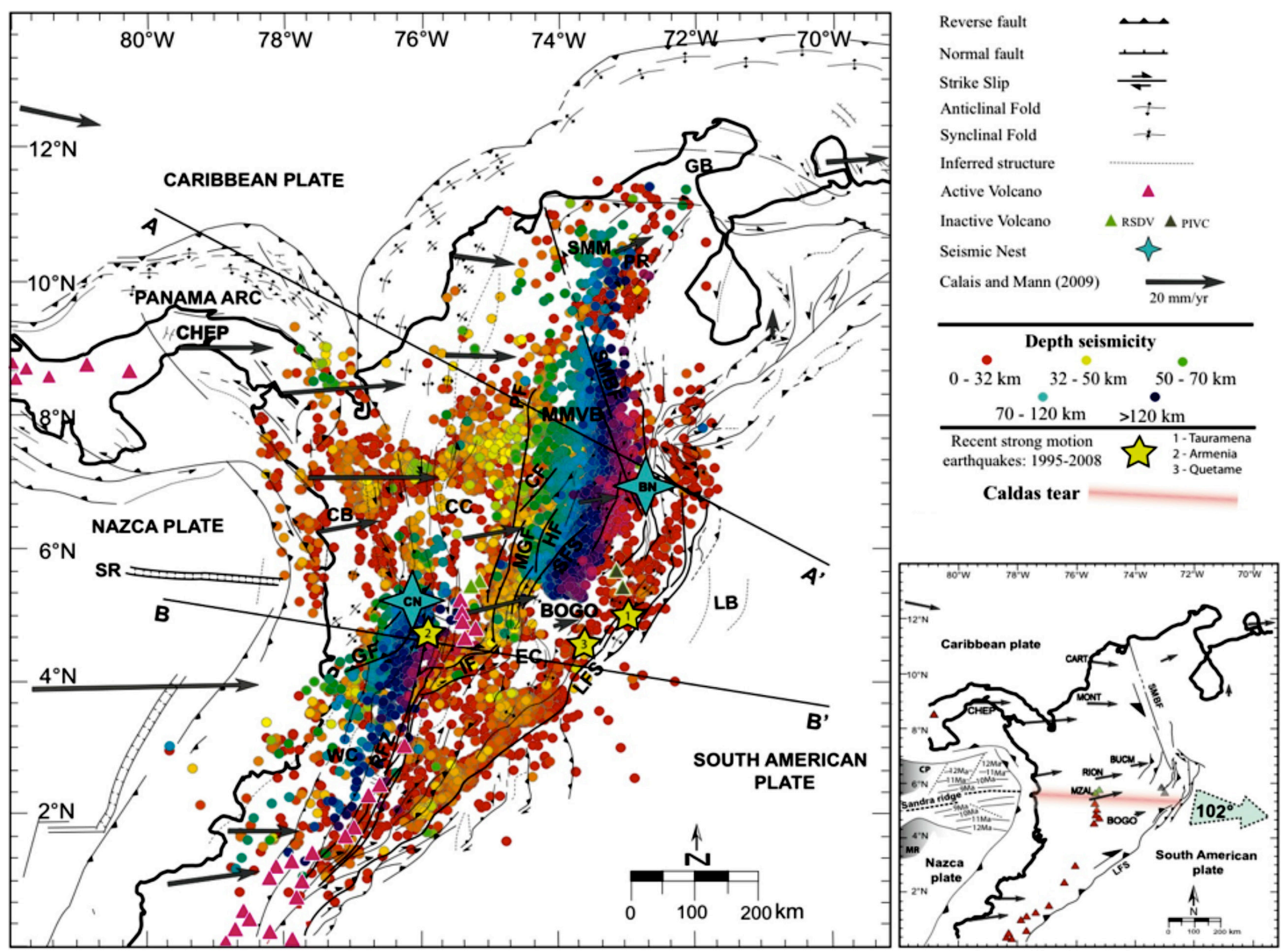

Figure 5. (a) Seismicity of Colombia and Western Venezuela. Figure from Vargas and Mann (2013, with permission). Shallow earthquakes (red and yellow dots) mark the thrust- and strike-slip motions between the Colombian microblocks caused by the internal deformation of the North Andean Block (data from the Colombian National Seismic Network). These belts of earthquakes mark the eastern, central, and western cordilleras and demonstrstrate that these mountain ranges are presently tectonically active. The intermediate-depth earthquakes (green, blue, and black dots) occur in a zone dipping to the east and is offset by the Caldas tear in the Nazca Plate that aligns with the offshore Sandra Ridge. (b) GPS measurements of crustal motion relative to the South American Plate (gray arrows with labels) consistent with the internal deformation of the North Andean Block (Fig. 4).

area density, especially in its cordillera (Table 1). The timing of speciation events for these plants and animals described in the next section show parallels with timing of geologic events in the tropics that I have reviewed above.

\section{Timing of speciation in orchids and their pollinators.} In October 2015, just before the V Scientific Conference on Andean Orchids in Cali, Colombia, I became aware of an important paper on molecular phylogenetic study of orchids by Tom Givnish and 15 others (Givnish et al. 2015), who sampled selected species from all of the orchid subfamilies. Although I do not have the technical background to judge the paper's methodology and also the number of species was limited, it was a multi-institutional collaboration of respected orchid scientists in the molecular phylogenetics, some of them pioneers in the field. Finally it was peer reviewed and published in a prestigious scientific journal. Although I have not parsed out the species endemic to the high elevations of the cordilleras and high intermontaine valleys in the neotropical nexus discussed above, the preponderance of neotropical species sampled by the authors occur there.

Their results are shown in Fig. 7, adapted from the Epidendroideae section of their Fig. 3. The vertical widths of the red horizontal lines are proportional to the rates of diversification (speciation rates minus 


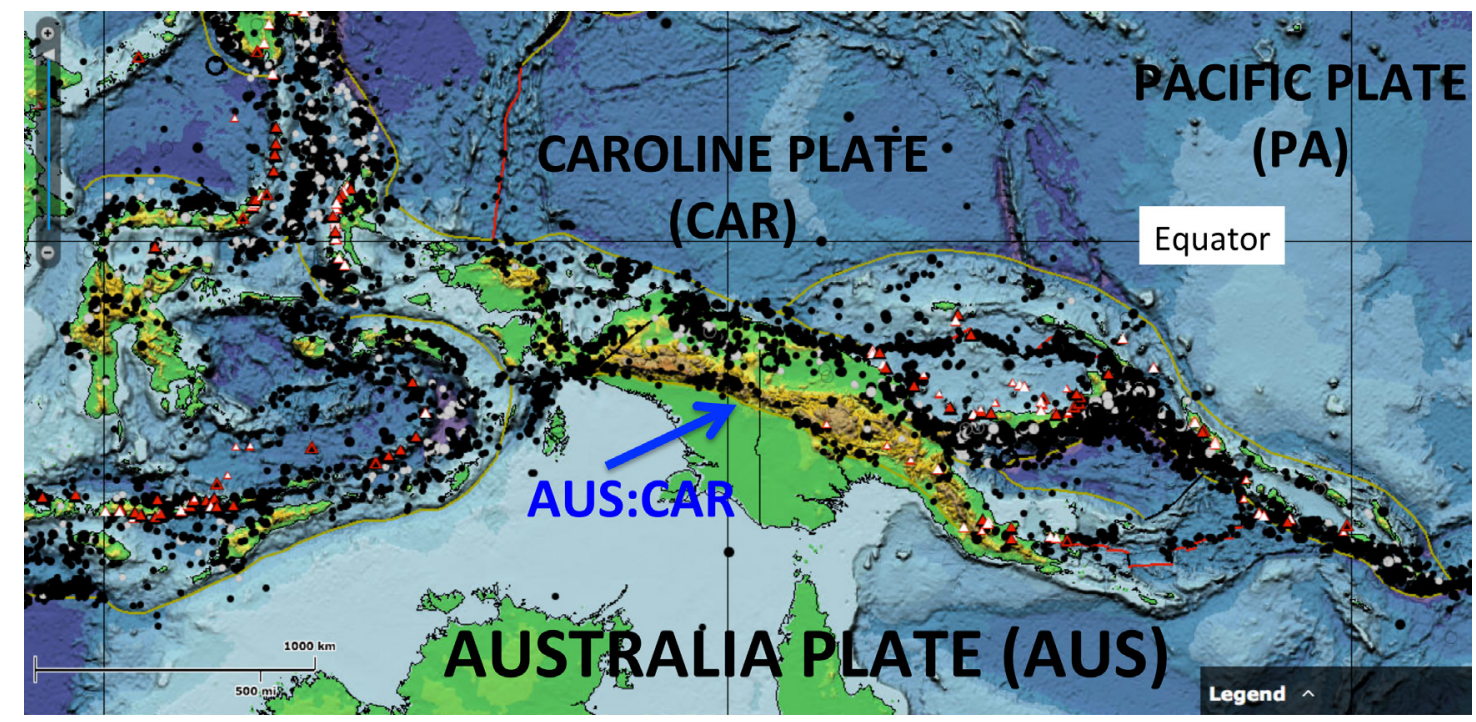

Figure 6. New Guinea Island: A tectonic counterpart in Asia of the NAB and Panama Block. The island is made up of West Papua (Irian Jayra, Indonesia) and Papua New Guinea). Along its spine is a 2000-km-long mountain chain that has the highest ongoing uplift rates in the world. This region was underwater as recently as 12 My ago. The range has 50 peaks above $3750 \mathrm{~m}$, the highest at $4884 \mathrm{~m}$. The Island also has among the most diverse orchid flora in the world. Same symbols as Figs. 1 and 2. Constructed from the online This Dynamic Planet online tools (http://nhb-arcims.si.edu/ ThisDynamicPlanet/). Same symbols as Fig. 1 and 3.

extinction rates). I also indicate graphically which subfamilies are New World and which are Old World. Immediately evident among the Epidendroideae are the accelerations of diversification beginning at about $15 \mathrm{Ma}$ BP and additional accelerations at 4-7 Ma BP.

These authors consider a number of factors that contribute to these jumps in diversification based on where the sampled species came from and their spatial distribution, what fauna pollinate them, their habitats, whether they are CAM, etc. They specifically identify the following factors as significant in descending order of significance:

A. Geographical factors: a) Distribution in tropical cordilleras, notably in the tropical Americas and New Guinea. $b$ ) tropical distribution.

B: Biological factors: i) CAM metabolism; ii) Epiphytism; iii) Pollinia pollination transport; iv) Other factors, such as deceit pollination, pollination by Lepidoptera and Euglossine bees.

Epiphytism itself is possibly linked to tropical cordillera through the orographic effects of mountain chains in increasing rainfall and producing high humidity and their effects on forest growth and vertical zonation of microclimates.

The chronology of diversification rates in preliminary results described in the pioneering paper by Givnish et al. (2015) are very exciting to this author because the timing of accelerations correspond to the geologic timing of mountain building events. A productive area of research is in the interactions of factors due to place, such as tropical climate and mountains and those due to biological changes. It is interesting that parallel studies of the chronologies of diversification of known pollinators known to pollinate orchids, such as euglossine bees (Ramírez et al. 2010) and some hummingbirds (McGuire et al. 2014). It is noteworthy that many of the branch points in the diversification of these orchid pollinators in their centers of diversity of these fauna are bracketed within the mid-Miocene to Quaternary (15 Ma to $0 \mathrm{Ma}$ ), a geological time frame for tectonic and volcanic events in the nexus of neotropical mountain building. This area of research is likely a productive direction, but further developments and refinements are beyond the scope of this paper. 
Time Before Present, My

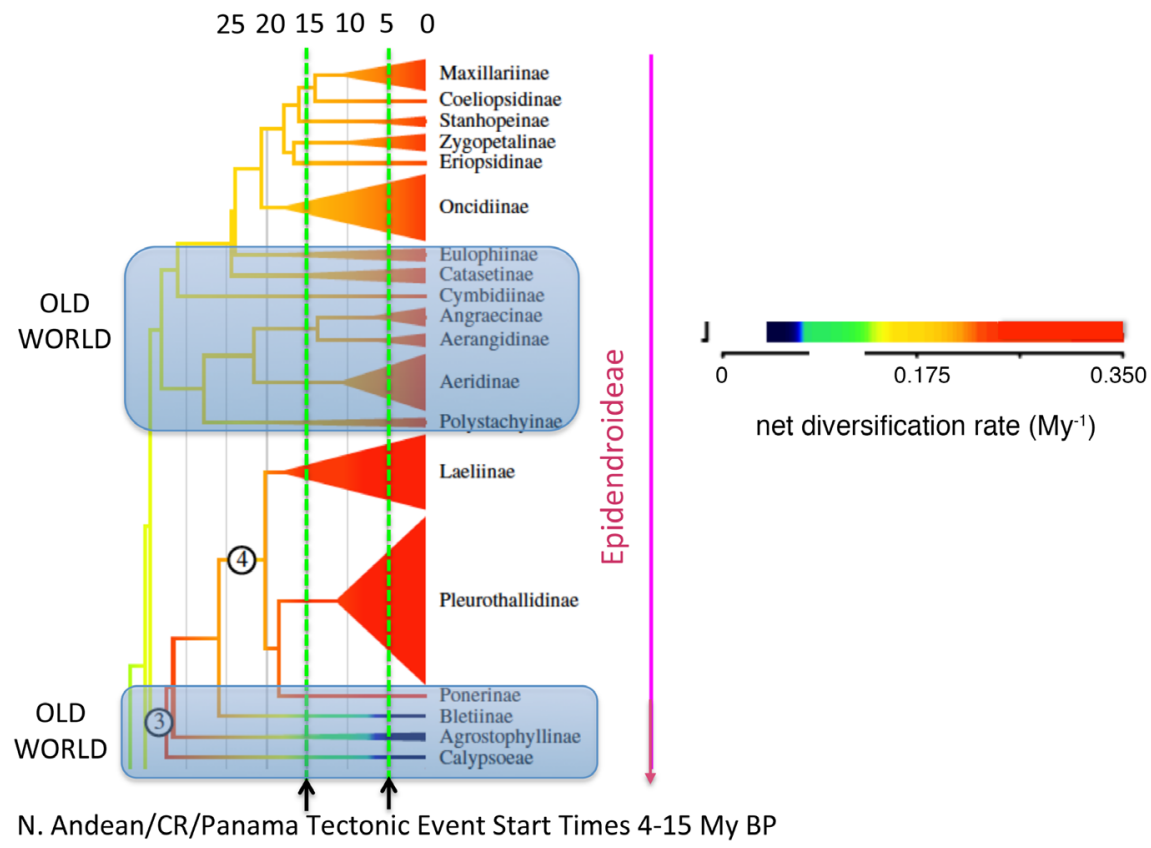

FIGURE 7. Neotropical orchid diversification rates for Epidendroideae over time based on phylogenetic data (adapted from Givnish et al., 2015, with permission). Subfamilies from the Old World are marked with enclosing boxes, otherwise the subfamilies are neotropical.

Possible insights into long-distance orchid dispersal between Central America and South America and the urgent need for additional information on sampling, taxonomy, and information flow about orchid species in eastern Panama and Andean Colombia. In the IV Scientific Conference on Andean Orchids in Guyaquil Ecuador, Kirby et al. (2012) described an attempt to investigate the biogeography of orchid species in the genus Camaridium (Orchidaceae: Maxillariinae). One of the motivations was to investigate the gene flow between SE Central America where most of the estimated 80 species in this genus are found and the northern Andes (Whitten et al. 2007, Blanco et al. 2007). Even though we authors collected nearly 2400 geographic distribution sites based on data from herbarium sheets, national and regional flora, and national and regional monographs, the results were only partially successful because of only a few dozen distribution sites in eastern Panama and Andean Colombia for only a handful of Camaridium species. This created an E-W gap of nearly $900 \mathrm{~km}$ between western Panama and Venezuela and N-S gap of more than $1000 \mathrm{~km}$ between western Panama and Ecuador for most of the known Camaridium species. Fortunately, the situation is rapidly changing due to purposeful collecting and taxonomy and to compilation of diverse information sources. Diego Bogarín and his Lankester Garden, and Panamanian and other coauthors recently published an impressive national checklist of orchids in Panama compiled from herbarium vouchers and published taxonomic treatments (Bogarín et al., 2014). Although sampling in eastern Panama is still relatively sparse compared to western Panama, Bogarín also described developing efforts to widen collaborative collections and identifications in eastern Panama that promise to help fill in this gap. In Colombia, the situation is also changing with the monumental national publication written by Betancourt, Sarmineto, ToroGonzâlez, and Valencia (First edition, April 2015) under the auspices of Colombian Ministry of the Interior and the Institute of Natural Sciences of the National University of Colombia in Bogotá. This publication used many of the same types of information sources as the earlier Bogarín et al. (2014) publication. Janet 
Valencia and Julio Betancur (Abstracts in V Scientific Conference on Andean Orchids in Cali, 2015) did an initial analysis of the patterns of diversity and biogeography from the results of this new compilation and promised that important work will continue and be updated with subsequent editions. Some of the sources of information in the 2015 publication and presentation came from the publication of regional monographs and checklists over the last decade or so, including Misas (2005), the Sociedad Colombiana de Orquidiología (2015), Ortíz Valdivieso and Uribe Vélez (2014), and many others published by the regional orchid societies in Colombia.

One of the sections of my 2015 presentation (Abstracts V Scientific Conference in Cali) included a discussion of the likely mechanisms of long-distance dispersal of orchids in the tropical Americas. These include:

1) Animal migration by birds and mammals;

2) Extreme winds in cyclones;

3) Downstream transport of log rafts during seasonal and cyclonic floods;

4) Earthquake-induced breaching of natural dams caused by huge landslides (e.g., 1987 in Ecuador);

5) Log-raft transport by shallow ocean currents.

All of these mechanisms are to varying extents seasonal and directional (largely from east to west). Moreover it should also be noted that the control of intermontaine valleys by the tectonic and volcanic processes described earlier also control the directions of movement of log rafts during floods, largely to the north-northeast in Colombia. When geographical sampling and taxonomic studies discussed earlier in this section are more advanced, it should be possible to use the seasonal and directional natures of these dispersal processes for hypothesis testing.

How many orchid species are there in Colombia? Since it is well established that mountains are crucibles for orchid diversity, an approach to estimate how many orchid species exist (or existed prior to European contact) in Colombia might be had by comparing the comparative lengths of cordilleras in Colombia with the length of the principal cordillera in Ecuador that has an estimated number of about 4000 known species. For Ecuador, the combined length of cordilleras is about $600 \mathrm{~km}$, whereas in Colombia, the multiple cordilleras total about $1900 \mathrm{~km}$. So this crude estimate suggest that there are $(1900 / 600 \times 4000)=$ about 12,700 orchid species in Colombia, But not all cordilleras are equal in average width, elevation, rainfall, yearly air temperatures, and latitudinal variations in westward winds from the Amazon and the Caribbean. For example, the main mountain chain in Ecuador is wider than all but one segment of the Colombian mountain chains. Allowing for these differences, perhaps this crude estimate of 10,000 orchid species in Colombia is a starting point on what to expect eventually should orchid surveys and taxonomic identifications trend in the ways that I hope continue.

ACKNOWLEDGEMENTS. I am indebted to my colleagues in orchid science for their knowledge and enthusiasm and encouragement of my research that have been the things that guide my continuing education in this field. I especially acknowledge my colleagues and friends at Lankester Gardens of the University of Costa Rica and their research associates: Franco Pupulin, Adam Karremans, Melissa Díaz, Diego Bogarín, Mario Blanco, and architect Carlos Ossenbach. I also thank current and former Orchid Botanists in Charge at Bosque de Paz Biological Reserve in Costa Rica: Melania Muñoz-Garcia, Adam Karremans, Melissa Díaz, and Noelia Belfort-Oconitrillo. It is my pleasure to call out the important contributions by James Ackerman to orchid science and orchid biogeography and his help in identifying Greater Antilles collection sites for species in the genus Camaridium. I also thank the Organizing Committee chaired by Nicola Sian Flanagan for inviting me to the Cali Conference and Alec Pridgeon and the other Organizing Committees for the Quito and Guyaquil Conferences for earlier invitations for invitations to speak at those Conferences. Finally, I have already acknowledged in the Prologue section the valuable insights of Calaway Dodson into some of the roles of geology in orchid diversity and biogeography.

\section{Literature Cited}

Ackerman, J. D. (2012). Abstract in the IV Andean Orchid Conservation Conference. Guayaquil, Ecuador.

Ackerman, J. D. (2014). Rapid transformation of orchid floras. Lankesteriana, 13(3), 157-164. doi: 10.15517/ lank.v13i3.14349

Baldwin, S. L., Fitzgerald, P. G. \& Webb, L. E. (2012). Tectonics of the New Guinea Region. Annual Review of Earth and Planetary Sciences, 40, 495-520. doi: 10.1146/annurev-earth-040809-152540

Betancur, J., Sarmiento, H., Toro-González, L. \& Valencia, J. (2015). Plan para el estudio y la conservación de las 
orquídeas en Colombia. Bogotá: Universidad Nacional de Colombia.

Blanco, M. A., Carnevali, G., Whitten, W. M., Singer, R. B., Koehler, S., Williams, N. H., Ojeda, I., Neubig, K. M. \& Endara, L. (2007). Generic realignments in Maxillariinae (Orchidceae). Lankesteriana, 7(3), 515537. doi: 10.15517/lank.v0i0.7935

Bogarín, D. (2011). How many orchid species in Costa Rica: A review of the latest discoveries. Lankesteriana, 11(3), 185-205. doi: 10.15517/lank.v11i3.18274

Bogarín, D., Pupulin, F., Arrocha, C. \& Warner, G. (2013). Orchids without borders: studying the hotspot of Costa Rica and Panama. Lankesteriana, 13(1-2), 13-26. doi: 10.15517/lank.v0i0.11529

Bogarín, D., Serracín, Z., Samudio, Z., Rincón, R. \& Pupulin, F. (2014). An updated checklist of the Orchidaceae of Panama, Lankesteriana, 14(3), 135- 364. doi: 10.15517/ lank.v14i3.17958

Collot, J.-Y., Michaud, F., Alvarado, A., Marcaillou, B., Sosson, M., Ratzov, G., Migeon, S., Calahorrano, A. \& Pazmino, A. (2009). Visión general de la morfología submarina del marge convergente de Ecuador - Sur de Colombia: implicaciones sobre la transferencia de masa y la edad del a subducción de la Cordillera de Carnegie. En: Collot, J.-Y., Sallares, V. \& Pazmino, A. (Eds.), Geología y geofísica marina y terrestre del Ecuador: desde la costa continental hasta las Islas Galápagos. Guayaquil: INOCAR.

Dodson, C. \& Escobar, R. (1993). Native Ecuadorian Orchids. Vol 1: Aa-Dracula. Brasil: Colina Livraria Editora.

Dodson, C. (2001). Native Ecuadorian Orchids. Vol 2: Dresslerella-Lepanthes. Sarasota: Dodson Publishing.

Dodson, C. (2002). Native Ecuadorian Orchids. Vol 3: Lepanthopsis-Oliveriana. Sarasota: Dodson Publishing. Dodson, C. (2003). Native Ecuadorian Orchids. Vol 4: Oncidium-Restrepiopsia. Sarasota: Dodson Publishing.

Dodson, C. (2004). Native Ecuadorian Orchids. Vol 5: Rodriguezia-Zygosepalum. Sarasota: Dodson Publishing.

Dodson, C. H. (2003). Why are there so many orchid species? Lankesteriana, 3(2), 99-103. doi: 10.15517/ lank.v3i2.23028

Givnish, T. J., Spalink, D., Ames, M., Lyon, S. P., Hunter, S. J., Zuluaga, A., Iles, W. J. D., Clements, M. A., Arroyo, M. T. K., Leebens-Mack, J., Endara, L., Kriebel, R. Neubig, K. M., Whitten, M. W., Williams, N. H. \& Cameron, K. M. (2015). Orchid phylogenomics and multiple drivers of their extraordinary diversification. Proceedings of the Royal Society B, 282, 1-10. doi: 10.1098/rspb.2015.1553

Hoorn, C., Wesselingh, F. P., ter Steege, H., Bermudez, M. A., Mora, A., Sevink, J., Sanmartín, I., Sanchez-
Meseguer, A., Anderson, C. L., Figuereido, J. P., Jaramillo, C., Riff, D., Negri, F. R., Hooghiemstra, H., Lundberg, J., Stadler, T., Särkinen, T. \& Antonelli, A. (2010). Amazonia through time: Andean uplift, climate change, landscape evolution, and biodiversity. Science, 330, 927-931.

Kirby, S. H. (2007). Geological processes and orchid biogeography with applications to southeast Central America. Lankesteriana, 7(1-2), 53-55. doi: 10.15517/ lank.v7i1-2.18436

Kirby, S. H. (2011). Active mountain-building and the distribution of "core" Maxillariinae species in tropical México and Central America. Lankesteriana, 11, 275291. doi: 10.15517/lank.v11i3.18283

Kirby, S. H., Blanco, M., Muñoz-Garcia, M., \& Villalobos, F. (2012). A preliminary biogeographic study of the Neotropical genus Camaridium (Orchidaceae: Maxillariinae). Abstract IV Scientific Conference on Andean Orchids. Guyaquil, Ecuador.

LaFemina, P. (2011). ICTP Workshop Report: Seismic Sources in Central America. Heredia, Costa Rica. Retrieved from http://indico.ictp.it/event/a10192/ material/0/14.pdf

LaFemina, P., Dixon, T. H., Govers, R., Norabuena, E., Turner, H., Saballos, A., Mattioli, G., Protti, M. \& Strauch, W. (2009). Fore-arc motion and Cocos Ridge collision in Central America. Geochemistry, Geophysics, Geosystems, 10, 1-21.doi: 10.1029/2008GC002181.

Mann, P. (1995). Geologic and tectonic development of the Caribbean plate boundary in Central and South America. Geological Society of America Special Paper, 295, 1-349.

Mann, P. \& Corrigan, J. (1990). Model for late Neogene deformation in Panama. Geology, 18, 558-562.

Mann, P., Rogers, R. D. \& Gahagan, L. (2006). Overview of plate tectonic history and its unresolved tectonic problems. In: J. Bundschuh \& G. E. Alvarado (Eds.), Central America: geology, resources and hazards, vol. 1. (pp. 201-232). London: Taylor and Francis.

McGuire, J. A., Witt, C. C, Remsen, J. V, Jr., Cori, A., Rabosky, D. L., Altshuler, D. L. \& Dudley, R. (2014). Molecular phylogenetics and the diversification of hummingbirds. Current Biology, 24, 910-916.

Misas-Urreta, G. (2006). Orquídeas de la Serranía del Baudó, Chocó, Colombia. Bogotá: Corporación Capitalina de Orquideología.

Nocquet, J-M., Villegas-Lanza, J. C., Chlieh, M., Mothes, P. A., Rolandone, F., Jarrin, P., Cisneros, D., Alvarado, A., Audin, L., Bondoux, F., Martin, X., Font, Y., Régnier, M., Vallée, M., Tran, T., Beauval, C., Maguiña Mendoza, J. M., Martinez, W., Tavera, H. \& Yepes, H. (2014). Motion of continental slivers and creeping subduction in the northern Andes. Nature Geoscience, 
7, 287-291. doi: 10.1038/ngeo2099

Ortiz-Valdivieso, P. \& Uribe Vélez, C. (2014). Orquídeas, tesoro de Colombia / Orchids - a Colombian treasure. Bogotá: Da Vinci Publicidad y Medios. 398 p. ISBN: 978-958-46-5329-1.

Ossenbach, C., Pupulin, F. \& Dressler, R. L. (2007). Orquídeas del istmo Centroamericano: catálogo y estado de conservación. Sabanilla, Costa Rica: Editorial 25 de Mayo.

Pupulin, F. (2002). Catálogo revisado y anotado de las Orchidacaceae de Costa Rica. Lankesteriana, 2(2), 1-88. doi: 10.15517/lank.v2i2.23095

Ramírez, S. R., Roubik, D. W., Skov, C. \& Pierce, N. E. (2010). Phylogeny, diversification patterns and historical biogeography of euglossine orchid bees (Hymenoptera: Apidae). Biological Journal of the Linnean Society, 100, 552-572.

Sak, P. B., Fisher, D. M., Gardner, T. W., Marshall, J. S. \& LaFemina, P. C. (2009). Rough crust subduction, forearc kinematics, and Quaternary uplift rates, Costa Rica segment of the Middle American Trench. Geological Society of America Bulletin, 121, 992-1012.

Schuiteman, A. \& de Vogel, E.F. (2001). Orchids of New Guinea I. National Herbarium of the Netherlands, University of Leiden Branch. Retrieved from http:// www.nhn.leidenuniv.nl

Schuiteman, A. \& de Vogel, E.F. (2002). Orchids of New Guinea II. National Herbarium of the Netherlands, University of Leiden Branch. Retrieved from http:// www.nhn.leidenuniv.nl

Schuiteman, A. \& de Vogel, E.F. (2005). Orchids of New Guinea III. National Herbarium of the Netherlands, University of Leiden Branch. Retrieved from http:// www.nhn.leidenuniv.nl

Schuiteman, A. \& de Vogel, E.F. (2006). Orchids of New Guinea IV. National Herbarium of the Netherlands, University of Leiden Branch. Retrieved from http:// www.nhn.leidenuniv.nl

Schuiteman, A. \& de Vogel, E.F. (2008). Orchids of New
Guinea V. National Herbarium of the Netherlands, University of Leiden Branch. Retrieved from http:// www.nhn.leidenuniv.nl

Schuiteman, A. \& de Vogel, E.F. (2010). Orchids of New Guinea VI. National Herbarium of the Netherlands, University of Leiden Branch. Retrieved from http:// www.nhn.leidenuniv.nl

Siebert, L., Simkin, T. \& Kimberly, P. (2011). Volcanoes of the World, Third Edition. California: University of California Press. 568 p. [ISBN: 9780520268777 ].

Simkin, T., Tilling, R., Vogt, P., Kirby, S. H., Kimberly, P. \& Stewart, D. B. (2006). This dynamic planet - world map of volcanoes, earthquakes, impact craters, and plate tectonics, U. S. Geological Survey Geologic Investigations Map I-2800, Washington, D.C., USA. Map and Poster. Online interactive version http:// mineralsciences.si.edu/tdpmap/

Sociedad Colombiana de Orquideología (Ed.). (2014). Orquídeas del Valle de Aburrá, Medellín. Colombia. Medellín: SCO.

Valencia, J. \& Betancur, J. (2015). Exploring the diversity patterns of orchids in Colombia. Abstract V Scientific Conference on Andean Orchids. Guyaquil, Ecuador.

Vargas, C.A. \& Mann, P. (2013). Tearing and breaking off of subducted slabs as the result of collision of the Panama Arc-Indenter with Northwestern South America. Bulletin of the Seismological Society of America, 103, 2025-2046. doi: 10.1785/0120120328

von Huene, R. \& Scholl, D.W. (1991). Observations at convergent margins concerning sediment subduction, sediment erosion, and the growth of continental crust. Reviews of Geophysics, 29, 279-316. doi: 10.1029/91RG00969

Whitten, W. M., Blanco, M. A., Williams, N. H., Koehler, S., Carnevali, G., Singer, R. B., Endara, L. \& Neubig, K. M. (2007). Molecular phylogenetics of Maxillaria and related genera (Orchidaceae: Cymbidieae) based on combined molecular data sets. American Journal of Botany, 94(11), 1860-1889. doi: 10.3732/ajb.94.11.1860 